\title{
Previous caesarean scar rupture: mortality averted a case report
}

\author{
Ajay Kumar $^{1}$, Anuj Singh ${ }^{2 *}$, V. B. Tripathi ${ }^{3}$
}

\begin{abstract}
${ }^{1}$ Department of Anaesthesiology and Critical Care, ${ }^{3}$ Department of Obstetrics and Gynaecology, Military Hospital, Dehradun, Uttarakhand, India

${ }^{2}$ Department of Anaesthesiology and Critical Care, Govt Hospital Joshimath, Uttarakhand, India
\end{abstract}

Received: 13 August 2020

Accepted: 16 September 2020

\section{*Correspondence:}

Dr. Anuj Singh,

E-mail: anujsingh.doc@gmail.com

Copyright: ( $\odot$ the author(s), publisher and licensee Medip Academy. This is an open-access article distributed under the terms of the Creative Commons Attribution Non-Commercial License, which permits unrestricted non-commercial

\begin{abstract}
Uterine rupture at the site of a previous cesarean section scar is an uncommon but catastrophic complication of pregnancy by associated with significant foetal and maternal mortality and morbidity. A 31-year old woman, G6P3A2L1 with previous lower segment cesarian section (LSCS), booked case was admitted at 37 week of gestation with complaint of leaking per vaginal $(\mathrm{P} / \mathrm{V})$ in our tertiary care centre. Patient had spontaneous labor pain, which subsided after few contractions and sustained hemorrhagic shock with utero placental insufficiency due to previous LSCS scar rupture. Due diligence and expeditious caesarean management strategy needs to be adopted in parturient with previous caesarean patients owing due to risk of scar rupture. Ultrasonography is a useful tool which can be used to assess women with previous cesarean section to carry out risk stratification for subsequent pregnancies.
\end{abstract}

Keywords: Caesarean section, Scar, Labor, Haemorrhage, Uteroplacental

\section{INTRODUCTION}

Caesarean sections (CS) are lifesaving when carried out with due diligence, indications and in cases of complicated normal delivery. The rates of CS varies from $28.1 \%$ in private sector and $12 \%$ in public sector health facilities. ${ }^{1}$ The risk for scar rupture with subsequent pregnancies is observed highest in the classical vertical scar with dreaded complications and lowest in low transverse incision cases. ${ }^{2,3}$ Now a days majority of CS are low transverse types. ${ }^{2}$ The risk of scar rupture is directly related to the status of previous scar viz. thinning out, ultrasound examination specifically directed to assessment of scar status during antenatal follow ups is an useful tool to carry our risk stratification. ${ }^{4}$ Scar rupture in parturient are associated with complications as post op sepsis, amniotic fluid embolism, haemorrhagic shock, disseminated intra vascular coagulation and even to maternal and foetal mortality. ${ }^{5}$
We present here, a case with complete rupture of a previous cesarean scar and ensued haemorrhagic shock being managed expeditiously without any residual maternal morbidity.

\section{CASE REPORT}

31 year old female, (weight $72.5 \mathrm{~kg}$; height $155 \mathrm{~cm}$ ), with an obstetric history of G6P3A2L1, 37 weeks period of gestation (POG), booked case, previous lower segment cesarian section (LSCS) with all antenatal record, was scheduled for caesarean section. Patient requested for trial of labor after caesarean (TOLAC). Premature atrial contractions Pre Anaesthesia check (PAC) work up was carried out in view of planned caesarean and was unremarkable and accepted in American society of anaesthesiologists (ASA-II) (pregnancy and post subtotal thyroidectomy). Lab, ultrasound and routine antenatal record pointed to uneventful progress of pregnancy. Laboratory parameters were all with in normal limits. 
During TOLAC patient had few contraction and crowning occurred and then spontaneously head of baby started receding back with loss of contractions and labor pain. Foetal heart sounds started decreasing (foetal bradycardia) on evaluation by hand held Doppler, delivery of foetus was carried out by obstetrician using vacuum and delivered baby hamded over to nurse for resuscitation. Patient had minimal labor pains and tachycardia (heart rate - 120/min), altered sensorium with cold peripheries and falling Glasgow coma scale (GCS) score. In view of previous LSCS status and sudden deterioration working diagnosis of uterine rupture was made and resuscitative measures were initiated by attending anaesthesiologist. Vitals included heart rate $-120 / \mathrm{min}$, respiratory rate- 35/min, blood mean arterial pressure (MAP) - $45 \mathrm{~mm} \mathrm{Hg}$ with GCS of 7. Patient was intubated using rapid sequence intubation technique with cuffed endotracheal tube (ET) tube - 7.5 $\mathrm{mm}$ ID/DV/Mc 3/CM-3 with injection ketamine - $50 \mathrm{mg}$ and injection succinyl choline $100 \mathrm{mg}$ intravenous (i.v) stat. The mentioned steps are carried out for stabilization of patient and definitive management by exploratory laparotomy and repair of scar rupture: right subclavian central line placement - for rapid infusion of crystalloids/colloids and vasopressor/inotropic agents, 2.0 litres of Ringer's lactate (RL) - infused with boluses of 250 $\mathrm{ml}$ and assessment of blood pressure done regularly, injection noradrenaline at the rate of $0.025 \mathrm{mcg} / \mathrm{kg} / \mathrm{min}-$ with target elevation of MAP more than $65 \mathrm{~mm} \mathrm{Hg}$, and transfusion of 2 units of whole blood with ongoing surgical management in operation theatre (OT).

Patient underwent exploratory laparotomy in OT under general anaesthesia (maintained with oxygen: air mixture of 1:1, sevoflurane minimum alveolar concentration (MAC)-0.7 and injection atracurium) with arterial line, electrocardiogram (ECG), temperature, and end-tidal carbon dioxide $\left(\mathrm{ETCO}_{2}\right)$ monitoring. Intra operative (op) findings were consistent with clinical diagnosis of ruptured previous caesarean scar along with urinary bladder tear, as confirmed on visual and dye injection. There was loss of approximately 2 litres of blood and patient's blood investigation revealed sharp fall in hemoglobin ( $\mathrm{Hb}$ ) level (admission value-10 mg/dl - after rupture-5 $\mathrm{mg} / \mathrm{dl}$ ), intra op patient received 4 units of blood, 4 units of fresh-frozen plasma (FFP) and RL-2 litres, surgery lasted for $200 \mathrm{~min}$ and successful uterine and urinary bladder repair was carried out. During the surgery hemodynamic stability was achieved with use of injection nor adrenaline and crystalloids and blood transfusion and injection nor adrenaline support was withdrawn gradually intra op in view of MAP $>80 \mathrm{~mm} \mathrm{Hg}$. The progress of hemodynamic parameter is depicted in Figure 1.

The patients' serial arterial blood gas (ABG) analysis were unremarkable. Post conclusion of surgery the patient was electively ventilated in intensive care unit (ICU) with transfusion of 2 units of packed red blood cells (PRBC) and ordered 4 hourly electrolyte, ABG, complete blood count $(\mathrm{CBC})$ assessment and radiograph chest. The next morning patient was extubated in view of stable hemodynamics and adequate weaning off indices. Patient received $\mathrm{O} 2$ by nasal prongs at the rate of 2 litres per minute. Patient remained hemodynamically stable and with no respiratory compromise transferred to obstetric and gynae ward on postoperative day 2 (POD2).

Over the period of management all blood investigations including coagulation profile remained within normal limits and its evident timely and active critical care and resuscitative facilities led to successful resuscitation of parturient and prevented other known complications of scar rupture with haemorrhagic shock.

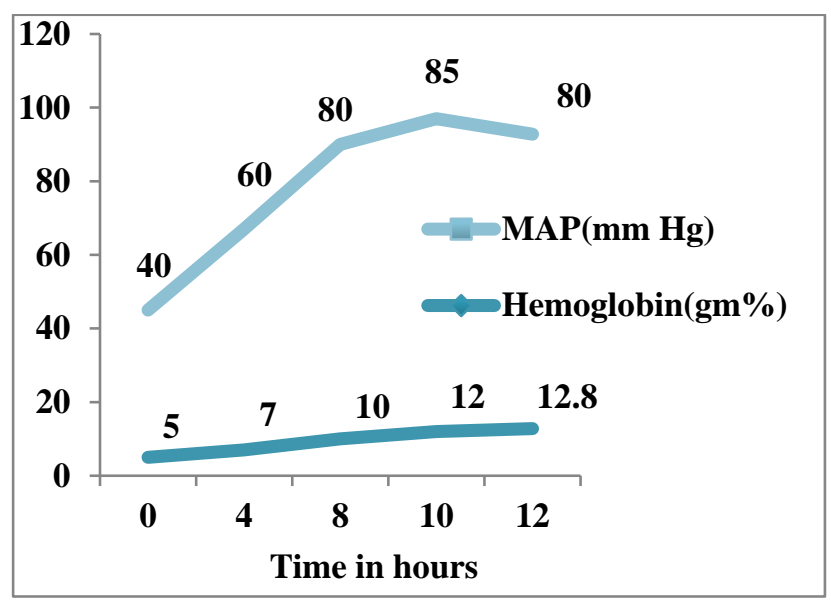

*MAP-mean arterial pressure

\section{Figure 1: Plot of $\mathrm{Hb}$ and MAP over the period of management.}

\section{DISCUSSION}

The incidence of uterine scar rupture varies between 0.7 5.1 per 10,000 deliveries in unscarred and scarred uterus. ${ }^{6}$ This incidences gets elevated from $22-74$ per 10,000 deliveries for parturient with previous caesarean sections and as per World Health Organizations (WHO) mean incidence worldwide is 5.3 per 10,000 births. ${ }^{7}$ Uterine scar rupture mostly occurs during labor, however they can occur any time in last trimester of pregnancy even before contraction starts. Scar rupture is divided into occult or incomplete rupture refers to a surgical scar separating but the visceral peritoneum staying intact (these are usually asymptomatic) or complete rupture. Complete scar rupture is further subdivided as traumatic and spontaneous with causes as enumerated in Table 1.

Key to uterine scar rupture management lies in its early detection on the basis of lower uterine segment (LUS), ultrasound based scar thickness and clinically in patients undergoing TOLAC. The classic signs sudden tearing uterine pain, vaginal haemorrhage, cessation of uterine contractions, regression of the fetus with any of the following should alert suspicion: cardiotocograph (CTG)foetal bradycardia, severe abdominal pain changes, chest or shoulder tip pain, sudden shortness of breath, scar pain and tenderness, abnormal vaginal bleeding or gross 
haematuria, cessation of efficient uterine contractions, maternal tachycardia, hypotension or shock and movement away of the presenting part. ${ }^{8}$

The combination of lower uterine segment thickness (values $>4.5 \mathrm{~mm}$ ) and scar thickness assessment with respect to myometrial thickness (cut off value- $2.15 \mathrm{~mm}$ ) can be a tool to prevent catastrophe due to scar rupture/dehiscence. ${ }^{9}$

Table 1: Subdivision of complete uterine scar rupture with causes.

\begin{tabular}{|ll|}
\hline Traumatic & Spontaneous \\
\hline Road traffic accident & Previous caesarean section \\
\hline $\begin{array}{l}\text { Incorrect ocytocic } \\
\text { dosage }\end{array}$ & $\begin{array}{l}\text { Weak uterine wall- } \\
\text { multiparity }\end{array}$ \\
\hline $\begin{array}{l}\text { Inadequately managed } \\
\text { TOLAC }\end{array}$ & Lateral cervical tear \\
\hline $\begin{array}{l}\text { Operative hysteroscopy } \\
\text { in non-pregnant } \\
\text { women }\end{array}$ \\
\hline
\end{tabular}

In cases of established scar rupture aim is always to carry out early resuscitative measures to prevent occurrence of complications as, due to damage to ureter/urinary bladder, amniotic fluid embolism, disseminated intravascular coagulation, haemorrhagic shock, coma even death. The management strategies in cases of established rupture and haemorrhagic shock, warrants replacement of blood loss, fluid resuscitation and in severe cases uses of inotropic agents to achieve hemodynamic stability with concurrent definitive surgical repair and precipitous labor for delivery of foetus. ${ }^{10}$

\section{CONCLUSION}

Parturient with previous caesarean section being given TOLAC are at risk of scar rupture and the incidence of rupture is high with previous vertical scar viz. low transverse scar caesareans. Scar rupture can be partial to complete with life threatening complication. All patients undergoing TOLAC must be managed with high suspicion for Scar rupture and OT readiness for emergency caesarean section and neonatal resuscitation. In addition all such cases can be evaluated by ultrasound for risk of rupture by evaluating the continuous myometrial band and its thickness, using a high frequency transducer probe. In situations as documented above prompt, expeditious and resuscitative role of anaesthesiologist is life saving and due preparedness will go long way in reducing maternal mortality.
Funding: No funding sources

Conflict of interest: None declared

Ethical approval: Not required

\section{REFERENCES}

1. District level household and facility survey (DLHS3). Mumbai: International Institute for Population Sciences. Available at: http://rchiips.org/PRCH3.html. Accessed on: 25 July 2020.

2. Jastrow N, Chaillet N, Roberge S, Morency AM, Lacasse Y, Bujold E. Sonographic lower uterine segment thickness and risk of uterine scar defect: asystematic review. J Obstet Gynaecol Can. 2010;32(4):321-7.

3. Ofili-Yebovi D, Ben-Nagi J, Sawyer E, Yazbek J, Lee C, Gonzalez J, et al. Deficient lower-segment Cesarean section scars: prevalence and risk factors. Ultrasound Obstet Gynecol. 2008;31(1):72-7.

4. Kok N, Wiersma IC, Opmeer BC, de Graaf IM, Mol BW, Pajkrt E. Sonographic measurement of lower uterine segment thickness to predict uterine rupture during a trial of labor in women with previous cesarean section: a meta-analysis. Ultrasound Obstet Gynecol. 2013;42:132-9.

5. Landon MB, Spong CY, Thom E, Hauth JC, Bloom SL, Varner MW, et al. Risk of uterine rupture with a trial of labor in women with multiple and single prior cesarean delivery. Obstet Gynecol. 2006;108(1):1220.

6. Zwart JJ, Richters JM, Ory F, de Vries JI, Bloemenkamp KW, van Roosmalen J. Uterine rupture in The Netherlands: a nation wide population based cohort study. BJOG. 2009;116(8):1069-78.

7. Hofmeyr GJ, Say L, Gulmezoglu AM. WHO systematic review of maternal mortality and morbidity :the prevalence of uterine rupture. BJOG. 2005;112(9):1221-8.

8. Guise JM, Denman MA, Emeis C, Marshall N, Walker M, Fu R, et al. Vaginal birth after cesarean: new insights. Evid Rep Technol Assess (FullRep). 2010;191:1-397.

9. Sharma C, Surya M, Soni A, Soni PK, Verma A, Verma S. Sonographic prediction of scar dehiscence in women with previous cesarean section. J Obstet Gynaecol India. 2015;65(2):97-103.

10. Krausz MM. Initial resuscitation of hemorrhagic shock. World J Emerg Surg. 2006;1:14.

Cite this article as: Kumar A, Singh A, Tripathi VB. Previous caesarean scar rupture: mortality averted a case report. Int J Reprod Contracept Obstet Gynecol 2020;9:4719-21. 